\title{
KETEPATAN MODEL PREDIKSI FINANCIAL DISTRESS PADA PERUSAHAAN RETAIL DI INDONESIA
}

\author{
Kartikasari $^{1}$ \\ Diyah Santi Hariyani ${ }^{2}$ \\ Universitas PGRI Madiun \\ tika.sari2695@gmail.com ${ }^{1}$ \\ dyarth@yahoo.com ${ }^{2}$
}

\section{Jurnal Nusantara \\ Aplikasi Manajemen Bisnis}

http://ojs.unpkediri.ac.id/index. php/manajemen/index

E-ISSN : 2528-0929

P-ISSN : 2549 - 5291

Diterima: 6 April 2019

Revisi : 8 Agustus 2019

Disetujui: 24 Oktober 2019

https://DOI

10.29407/nusamba.v4i2.12651

Abstract

This study aims to indentify and analyze the accuracy models of Financial Distress in retail companies listed on the Indonesian Stock Exchange in 2015-2017 using the Ohlson Model, Fulmer Model, CA-Score Model and Zavgren Model. The data used in this study was secondary data derived from the financial statements of retail companies found on the Indonesian Stock Exchange. The data analysis technique used was inferential statistics and Kruskall-Wallis test. The results of this study indicated that Ohlson's model is best at predicting Financial Distress in retail companies in Indonesia with an accuracy rate of $83.33 \%$, CA-Score Model with 30\% accuracy rate, as well as the Fulmer Model and Zavgren Model with an accuracy rate of $0.00 \%$.

Keywords: Financial Distress, Ohlson Model, Fulmer Model, CA-Score Model, Zavgren Model. 


\section{PENDAHULUAN}

Pemulihan ekonomi global yang masih lambat dan tidak merata pada kondisi sekarang ini berdampak pada sektor ritel yang semakin sepi, dan banyak pusat perbelanjaan yang menutup bisnisnya dikarenaan mengalami penurunan pendapatan setiap harinya, menyebabkan perusahaan mengalami kesulitan keuangan (Financial Distress).

Menurut (Atmaja, 2008) "Financial Distress adalah kondisi dimana perusahaan mengalami kesulitan keuangan dan terancam bangkrut. Jika perusahaan mengalami kebangkrutan, maka akan timbul biaya kebangkrutan (Bancrupty Cost) yang disebabkan oleh keterpaksaan menjual aktiva dibawah harga pasar, biaya likuidasi perusahaan, rusaknya aktiva tetap dimakan waktu untuk sebelum terjual dan sebagainya".

Pada tahun 2017 terasa getir bagi beberapa ritel modern di Indonesia. Beberapa ritel modern akhirnya tutup akibat perubahan pola konsumsi dan penurunan daya beli masyarakat, besarnya biaya operasional tidak dapat ditutupi dengan pendapatannya. Akibat kerugian yang terus terjadi menyebabkan perusahaan akhirnya harus menutup gerainya. Dikutip dari Riset HaloMoney.co.id, Asosiasi Pengusaha Ritel Indonesia (Aprindo) melansir industri ritel hanya mengantongi pertumbuhan dibawah lima persen sepanjang Januari - Juni 2017. Lesunya pasar ritel Indonesia juga tercermin dalam riset Global Retail Developmen Index yang di keluarkan ATKearny Tahun 2017 Indonesia menempati posisi delapan atau turun tiga peringkat dari tahun 2016. ATKearny menyebut penjualan ritel di Indonesia mencapai US\$ 350 miliar atau hanya naik 8,02 persen dari tahun 2016. Sepanjang tahun 2017 ada lima brand ritel yang menutup gerainya yaitu Lotus Departemen Store (PT. Mitra Adi Perkasa), Ramayana (PT. Ramayana Lestari Sentosa Tbk), PT.Matahari Departement Store tbk (LPPF), Debenhams (milik PT, Mitra Adi Perkasa Tbk), dan 7 - Eleven (PT. Modern Internasional Tbk).

Selain PT. Mitra Adiperkasa Tbk, yang mengalami penurunan labanya dan menutup sebagian gerainya yaitu PT. Ramayana Lestari Sentosa Tbk (RALS). PT. Matahari Departemen Store Tbk (LPPF) juga mengalami penutupan gerai tetapi bukan karena penurunan laba melainkan karena sebagian besar akibat buruknya kinerja perusahaan. Kondisi ini menunjukan adanya penurunan dan kenaikan laba bersih dan total hutang yang diperoleh dari 19 perusahaan ritel di Indonesia. Permasalahan penurunan dan peningkatan laba yang tidak menentu atau fluktuatif dan total hutang yang kian meningkat dapat berisiko pada perusahaan yang mengalami kesulitan keuangan atau Financial Distress bahkan perusahaan sampai mengalami kebangkrutan atau gulung tikar seperti yang terjadi pada tutupnya gerai 7- Eleven milik PT. Modern Internasional Tbk (MDRN).

Dilihat dari fenomena yang terjadi diatas maka diperlukan analisis kebangkrutan untuk memperoleh peringatan awal kebangkrutan. Pada umumnya kemungkinan terjadinya Financial Distress semakin meningkat yaitu dengan meningkatnya hutang, jadi logikanya jika hutang semakin besar maka beban biaya bunga akan meningkat dan probabilitas penghasilan semakin menurun maka dapat dikatakan perusahaan tersebut mengalami kesulitan keuangan atau Financial Distress. Agar kebangkrutan tersebut tidak benar-benar terjadi pada perusahaan, maka perusahaan dapat mengantisipasi dengan membuat strategi untuk menghadapi kesulitan yang mungkin akan terjadi jika perusahaan mengalami Financial Distress.

Berbagai analisis atau metode dikembangkan untuk memprediksi awal kebangkrutan perusahaan. Analisis dalam penelitian ini yang digunakan yaitu analisis prediksi Financial Distress dengan model Ohlson, Fulmer, CA-Score dan Zavgren. Dimana analisis ini mengacu pada rasio-rasio keuangan perusahaan. Pada penelitian sebelumnya untuk menganalisis kebangkrutan menggunakan metode Altman seperti yang dilakukan oleh (Panigrahi, 2019) pada perusahaan farmasi (Aurobindo Pharma, Lupin Pharma, Dr. Reddy's Labs dan Sun Pharma) periode 2012-2017. (Samanhyia, Oware and Anisom-yaansah, 2016) memprediksi kebangkrutan pada perusahaan perbankan di Ghana negara Afrika. (Amoa-Gyarteng, 2019) pada perusahaan 
sekuritas di Amerika Serikat. (Supriyanto and Darmawan, 2018) pada perusahaan pertambangan yang terdaftar di Bursa Efek Indonesia periode 2011-2014.

Sedangkan penelitian yang telah dilakukan oleh (Wulandari, dkk, 2014) menggunakan model Altman, Springate, Ohlson, Fulmer, CA-score dan Zmijewski dalam memprediksi Financial Distress pada perusahaan Food and Beverage hasilnya adalah model prediksi Ohlson yang paling akurat dalam memprediksi perusahaan Food and Beverage dibanding model prediksi lain. (Kusumaningtyas,2017) dalam melakukan Prediksi kebangkrutan dengan menggunakan model Zmijewski, Springate dan Fulmer pada perusahaan Ritel di Bursa Efek Indonesia hasil yang diperoleh yaitu model Springate merupakan model yang paling akurat dibandingkan dengan model Zmijewski dan model Fulmer. (Agarwal and Patni, 2019) pada perusahaan di India yang sudah mengalami kebangkrutan selam 10 tahun terakhir dari tahun pertama terjadi kebangkrutan dengan model Springate, Ohlson, Zmijewski, Grover dan Altman. (Ashraf, G. S. Félix and Serrasqueiro, 2019) pada perusahaan Pakistan dengan menggunakan model D-Skor Blum, Ohlson, Taffler, Zmijewski.

Dari penelitian terdahulu diatas dapat diketahui bahwa setiap model dalam prediksi kebangkrutan mempunyai hasil yang berbeda untuk setiap sub sektor perusahaan, diharapkan dengan adanya model prediksi analisis kebangkrutan ini pihak manajemen tidak lagi menghabiskan waktu untuk menghindari kebangkrutan dan pihak investor dapat mengetahui kondisi keuangan perusahaan yang akan ditanami saham supaya dapat memperoleh Capital Gaint.

Beberapa penelitian terdahulu tentang prediksi kebangkrutan suatu perusahaan telah banyak dilakukan di Indonesia. Akan tetapi kurangnya penelitian tentang perusahaan Ritel serta perbandingan model prediksi kebangkrutan yang tepat terutama model CA-Score masih banyak peneliti yang belum meneliti dengan model CA-Score, sehingga penelitian ini bertujuan untuk menganalisis laporan keuangan perusahaan dan memprediksi tingkat Financial Distress yang dialami perusahaan ritel di Indonesia yaitu :

1. Untuk memberikan bukti empiris model prediksi manakah yang paling akurat dalam memprediksi Financial Distress pada perusahaan retail yang terdaftar di Bursa efek indonesia tahun 2015-2017.

2. Untuk memberikan bukti empiris terdapat perbedaan pada hasil uji dan perusahaan apa saja yang diprediksi akan mengalami Financial Distress.

\section{TINJAUAN PUSTAKA}

\section{Penyebab kebangkrutan}

(Musthafa, 2017) menyatakan "kesulitan keuangan oleh perusahaan akan meyebabkan penciutan usaha, usaha menjadi lebih kecil, bahkan dalam kesulitan yang lebih berat akan menyebabkan perusahaan tersebut ditutup". Dengan adanya kesulitan keuangan tersebut perusahaan dapat dikatakan gagal. Kegagalan perusahaan tidak saja karena kesulitan keuangan, tetapi juga dalam kenyataan tidak jarang perusahaan mengalami kesulitan dalam persaingan sehingga memperkecil skala perusahaan, atau bahkan menutup perusahaan atau likuidasi.

Kegagalan perusahaan ada dua macam, yaitu terdiri dari:

1. Economic Failur dimana pendapatan perusahaan tidak dapat menutupi jumlah biayanya, termasuk biaya modal misalnya biaya listrik, biaya telpon, biaya bunga dan lain - lain.

2. Business Failur dimana perusahaan yang gagal menimbulkan kerugian bagi krediturnya, misalnya tidak dapat membayar hutang perusahaan.

Aghajani dan Jouzbarkand (2012), financial distress adalah situasi yang menunjukkan perusahaan atau seseorang sedang berada dalam kondisi keuangan yang lemah. Anggarini dan Ardiyanto (2010) menjelaskan bahwa perusahaan yang mengalami financial distress akan menghadapi beberapa kondisi, yaitu perusahaan mengalami kegagalan pembayaran kembali utang yang telah jatuh tempo dan perusahaan tersebut berada dalam kondisi yang tidak solvable yaitu 
ketidakmampuan seseorang atau organisasi untuk membayar utang tepat pada waktunya atau keadaan yang menunjukkan jumlah kewajiban melebihi harta.

Studi pertama di bidang prediksi kebangkrutan dilakukan oleh (Woodlock, 1939). Ada banyak teknik yang tersedia untuk mengukur kesehatan keuangan perusahaan. Berbagai pendekatan telah diadopsi untuk mengukur kinerja keuangan perusahaan salah satunya menggunakan model prediksi kebangkrutan. Model prediksi kebangkrutan telah digunakan untuk menganalisis kinerja perusahaan dari berbagai industri. Banyak studi empiris yang berharga di negara maju telah menggunakan model yang berbeda untuk memprediksi kinerja perusahaan. Di antara banyak metode yang tersedia untuk memprediksi kebangkrutan hanya beberapa dari mereka yang lebih terkenal dan mapan. Dalam memprediksi kebangkrutan, model-model ini memiliki tingkat akurasi yang berbeda berdasarkan pengukuran yang digunakan (Purnajaya \& Merkusiwati, 2014). Rasio keuangan diidentifikasi sebagai salah satu faktor terpenting yang mempengaruhi akurasi ketika mengembangkan model prediksi kebangkrutan (Liang, Tsai \& Shih, 2016). (Pacey \& Pham, 1990) merujuk (Altman, 1984) menyatakan bahwa tingkat akurasi yang tinggi berkisar 70-95\% dapat diprediksi dengan model kegagalan bisnis.

Beberapa model prediksi financial distress dikembangkan dan ditemukan dengan formulasi data keuangan, namun setiap model prediksi memiliki tingkat akurasinya sendiri pada sektor tertentu. Sehingga dalam penelitian ini kami akan menganalisis kebangkrutan pada perusahaan ritel dengan model Ohlson, Fulmer, CA-Score dan Zavgren.

\section{METODOLOGI PENELITIAN}

Penelitian ini menggunakan data sekunder yang diperoleh dari data laporan keuangan perusahaan ritel tahun 2015-2017 dari www.idx.id. Penelitian ini dimaksudkan untuk menganalisis perbandingan prediksi Finacial Distress dengan model Ohlson, Fulmer, CA-Score dan Zavgren periode penelitian tahun 2015 - 2017 dan model terbaik manakah yang digunakan dalam memprediksi Financial Distress pada perusahaan ritel.

\section{Model Prediksi Financial Distress}

Pada bagian ini akan diuraikan lebih detail 4 (empat) model prediksi Financial Distress. Model - model tersebut adalah metode Ohlson, Metode Fulmer, Metode CA-score dan Metode Zavgren.

\section{Model Ohlson}

Ohlson menggunakan analisis logistik untuk mengembangkan model prediksi kebangkrutan dengan sembilan indikator independen". Prosedur perbandingan yang digunakan menggunakan prosedure berdasarkan persamaan model Ohlson" adalah sebagai berikut :

$\mathrm{O}=-1,32-0,407 \mathrm{x}_{1}+6,03 \mathrm{x}_{2}-1,43 \mathrm{x}_{3}+0,0757 \mathrm{x}_{4}-2,37 \mathrm{x}_{5}-1,83 \mathrm{x}_{6}+0,285 \mathrm{x}_{7}-1,72 \mathrm{x}_{8}-0,521 \mathrm{x}_{9}$

Dimana:

$x_{1}=\log ($ Total Aset/GNP price level lindek)-SIZE

$x_{2}=$ Total Liabilities/Total Assets (TLTA)

$x_{3}=$ Working capital/Total asets (WCTA)

$x_{4}=$ Current Liabilities/Current Assets (CLCA)

$x_{5}=1$ jika total liabilities > total assets; 0 jika sebaliknya

$x_{6}=$ Net income/ Total assets (NITA)

$x_{7}=$ Cash flow from operation/total liabilities (CFOTL)

$x_{8}=1$ jika Net income negatif; 0 jika sebaliknya

$x_{9}=$ Perubahan pada laba bersih

\section{Model Fulmer}


Model kebangkrutan Fulmer H-score menggunakan analisa Stepwise multiple discriminant. Adapun model Rumus metode Fulmer adalah sebagai berikut:

H Faktor $=5,528 x_{1}+0,212 x_{2}+0,73 x_{3}+1,27 x_{4}-0,12 x_{5}+2,335 x_{6}+0,575 x_{7}+1,083 x_{8}+0.894 x_{9}$ $-6,075$

Dimana:

$X_{1}=$ Retairned Earning / Total Asset

$X_{2}=$ Sales $/$ Total Assets

$X_{3}=$ EBIT/ Equity

$X_{4}=$ Cash Flow / Total Debt

$X_{5}=$ Debt $/$ Total

$X_{6}=$ Current Liabilities $/$ Total Assets

$X_{7}=$ Log Fix Asset

$X_{8}=$ Working Capital / Total Debt

$X_{9}=\log (E B I T) /$ Interest

\section{Model CA - Score}

Model CA-Score dikembangkan dibawah pimpinan Jean Legault University of Quebee di montreal, menggunakan analisis diskriminatif beberapa tahap untuk menganalisis tingkat kegagalan perusahaan di Kanada”. Model ini menggunakan rumus sebagai berikut :

$\mathrm{CA}-\mathrm{Score}=$

$$
4.5913 x_{1}+4,508 x_{2}+0,3936 x_{3}-2,7616
$$

Dimana :

CA-Score $=$ Bankrupty index

$\mathrm{x}_{1} \quad=$ Shareholder invesment/assets

$\mathrm{x}_{2} \quad=\mathrm{EBT}+$ Financial expenses $/$ assets

$\mathrm{x}_{3} \quad=$ sales $/$ assets

\section{Model Zavgren}

Menurut (Rahmawati dan Agustina, 2010) dari "berbagai penelitian klasik, disimpulkan bahwa analisis diskriminan dan analisis logit banyak digunakan karena 2 alasan yaitu (1) analisis ini merupakan teknik pertama yang digunakan untuk memprediksi kesulitan keuangan dan dikembangkan menjadi teknik - teknik yang lain". "Aplikasi dari model logit Zavgren membutuhkan 4 langkah, yaitu pertama adalah serangkaian 7 rasio keuangan dihitung, kedua adalah setiap rasio dikalikan dengan koefisien khusus, ketiga adalah nilai atau hasil yang diperoleh dijumlahkan secara bersama (y), dan akhirnya probabilitas kebangkrutan perusahaan dikalkulasi dengan fungsi probabilitas logit: Model Zavgren mendefinisikan sebagai berikut: $\mathrm{Y}=0,23883-0,108(I N V)-1,583($ REC $)-10.78(C A S H)+3,074($ QUICK $)+0,481(R O I)+4,35$

$$
(D E B T)+0,11(T U R N)
$$

Dimana :

INV $\quad=$ Persediaan penjualan / Penjualan

REC = Piutang / Persediaan

CASH $=$ Kas $/$ Total Aktiva

QUICK =Aktiva Lancar / Hutang Lancar

ROI = Laba Opersional Bersih / (Total Aktiva - Hutang Lancar)

$D E B \quad=$ Hutang Jangka Panjang / (Total Aktiva - Hutang Lancar)

$T U R N=$ Penjualan / (Modal Kerja + Aktiva Tetap)

Setelah didapatkan hasil dari metode logit diatas, "maka data yang diuji lagi dengan statistik karena model logit tidak mempunyai titik cut off untuk mendapatkan tingkat kepastian yang tinggi". Alat statistik yang digunakan adalah sebagai berikut : standar deviasi (untuk $n$ Tsv $1<$ 30) dengan rumus sebagai berikut : 
Dimana :

$$
S D=\sqrt{ }\left(\frac{\sum(x 1-x)^{2}}{\mathrm{n}-1}\right.
$$

$$
\begin{array}{ll}
\mathrm{SD} & =\text { Standart Deviasi } \\
\mathrm{x}_{\mathrm{i}} & =\text { Data ke }-1 \\
\mathrm{x} & =\text { Rata-rata industri } \\
\mathrm{n} & =\text { Jumlah sample }
\end{array}
$$

Rentang interval, dengan tingkat keyakinan 95\% (@ = 0,05)

$$
X-\operatorname{ta} \underset{\sqrt{n}}{2} \frac{\mathrm{S}}{\sqrt{n}}<\mathrm{U}<X+\alpha / \underset{\sqrt{n}}{2}
$$

Keterangan :

$$
\begin{array}{ll}
\mathrm{S} & =\text { Standar Deviasi } \\
\mathrm{x} & =\text { Rata }- \text { rata industri } \\
\alpha & =\text { Koefisien alfa } \\
\mathrm{t} & =\text { Koefisien } \mathrm{t} \text { tabel } \\
\mathrm{n} & =\text { Jumlah Sampel }
\end{array}
$$

\section{Teknik analisis data}

Dalam pengujian hipotesis ini terdapat 2 kemungkinan yaitu :

\section{Data Normal}

Data dikatakan normal yaitu jika data yang dianalisis berdistribusi normal maka uji yang digunakan yaitu

a. Uji Normalitas Data

Model data memenuhi asumsi normalitas dengan dasar pengambilan keputuasan adalah Jika nilai probabilitas $>0,05$ dan sebaliknya, jika nilai probabilitas $\leq 0,05$ maka model regresi tidak memenuhi asumsi normalitas pengujian menggunakan Uji Kolmogorof Smirnov.

b. Uji Homogenitas

Uji Homogenitas bertujuan "untuk menguji apakah dalam model data variabel mempunyai distribusi homogen atau tidak. Model data memenuhi asumsi homogenitas dengan dasar pengambilan keputusan adalah, jika nilai probalitas $\geq 0,05$ dan sebaliknya, jika nilai probabilitas $\leq 0,05$, maka model regresi tidak memenuhi asumsi homogenitas.

c. Pengujian Hipotesis

Uji Beda (one way Anova)

Uji One Way Anova atau Analysis of Variance digunakan untuk pengujian lebih dari dua sample, dalam penelitian ini uji One Way Anova digunakan untuk mengetahui perbandingan model Ohlson, Fulmer, CA - Score, dan Zavgren dalam memprediksi Financial Distress pada perusahaan Ritel di Indonesia. Uji $\mathrm{F}$ dilakukan untuk membandingkan $\mathrm{F}$ hitung dengan $\mathrm{F}$ tabel pada tingkat signifikan 5\% $(0,05)$ '. Jika $\mathrm{F}$ hitung $>\mathrm{F}$ tabel maka variabel bebas dapat menerangkan terikatnya, Artinya ada pengaruh antara model prediksi dengan prediksi kebangkrutan.

1) Jika $\mathrm{F}$ hitung $<\mathrm{F}$ tabel atau p value $>$ a dikatakan tidak signifikan, dan hipotesis penelitian ditolak.

2) Jika F hitung > F tabel atau p value < a dikatakan tidak signifikan, dan hipotesis penelitian diterima.

Syarat dari uji Hipotesisi dalam penelitian ini yaitu

$\mathrm{H}_{0}=$ Keempat rata - rata model tidak terdapat perbedaan.

$\mathrm{H}_{1}=$ keempat rata - rata model terdapat perbedaan. 


\section{Data Tidak Normal}

Dalam uji hipotesis data tidak berdistribusi normal maka uji yang digunakan yaitu uji Kruskall Wallis. Dalam uji Kruskall Wallis adapun syaratnya yaitu :

$\mathrm{H}_{0}=$ Keempat model identik (keempat model financial distress tidak berbeda secara signifikan.

$\mathrm{H}_{1}=$ Keempat model financial distress berbeda secara signifikan.

Tingkat signifikansi perbedaan pada uji Kruskall Waliss yaitu jika Asymp. Sig dibawah 0,05 maka terdapat perbedaan, bila diatas 0,05 tidak terdapat perbedaan

\section{ANALISA DAN PEMBAHASAN}

Hasil olah data dari masing-masing model digunakan dalam memprediksi Financial Distress pada perusahaan ritel yang terdaftar di Bursa Efek Indonesia. Dan berikut adalah tabel perbandingan masing-masing model untuk melihat model yang paling tinggi tingkat akurasinya dalam memprediksi Financial Distress.

\begin{tabular}{|l|r|r|r|r|}
\hline \multirow{2}{*}{ Kategori } & \multicolumn{4}{|c|}{ Prosentase Perbandingan Tiga Model } \\
\cline { 2 - 5 } & Ohlson & Fulmer & \multicolumn{1}{c|}{$\begin{array}{c}\text { CA- } \\
\text { Score }\end{array}$} & Zavgren \\
\hline Sehat & $6,67 \%$ & $100 \%$ & $70 \%$ & $96,67 \%$ \\
\hline $\begin{array}{l}\text { Grey } \\
\text { Area }\end{array}$ & $10 \%$ & - & - & $3,33 \%$ \\
\hline Bangkrut & $83,33 \%$ & - & $30 \%$ & - \\
\hline
\end{tabular}

Sumber : Data Diolah

Dari hasil diatas dapat disimpulkan bahwa Model Ohlson adalah model yang paling tepat untuk memprediksi perusahaan ritel dengan akurasi 83,33\% kemudian Model CA-Score dengan tingkat akurasi $30 \%$ berada dalam kategori tidak sehat, kemudian Zavgren dengan tingkat akurasi 3,33\% perusahaan berada dalam kategori Grey Area dan model Fulmer dengan tingkat akurasi $0,00 \%$. Hasil ini sejalan dengan penelitian yang dilakukan oleh (Wulandari, dkk, 2014) dengan judul "Analisis Perbandingan Model Altman, Springate, Ohlson, Fulmer, CA-Score dan Zmijewski dalam memprediksi Financial Distress pada perusahaan Food And Beverage yang terdaftar di BEI" dimana hasil penelitian ini "menyatakan bahwa model Ohlson memiliki tingkat akurasi yang lebih tinggi dibandingkan dengan model lain".

\section{Berdasarkan model prediksi yang paling akurat perusahaan yang mengalami Financial Distress.}

a. Analisis Tambahan Prediksi Financial Distress

Berdasarkan perbandingan hasil prediksi pada beberapa model yang ditampilkal pada tabel

1, tampak bahwa semua model perhitungan untuk prediksi tingkat kesehatan perusahaan menunjukkan hasil relatif yang berbeda-beda

Tabel 1 Perbandingan hasil Perhitungan Kesehatan Perusahaan

\begin{tabular}{|c|l|c|c|c|c|}
\hline \multirow{2}{*}{ No } & \multirow{2}{*}{ Kode } & \multicolumn{4}{|c|}{2015} \\
\cline { 3 - 6 } & & O & F & C & Z \\
\hline 1 & AMRT & TS & S & S & S \\
\hline 2 & CSAP & TS & S & S & S \\
\hline 3 & ERAA & TS & S & S & S \\
\hline 4 & HERO & S & S & S & S \\
\hline 5 & LPPF & TS & S & S & S \\
\hline 6 & MAPI & TS & S & S & S \\
\hline
\end{tabular}

\begin{tabular}{|c|c|c|c|}
\hline \multicolumn{4}{|c|}{2016} \\
\hline O & F & C & Z \\
\hline TS & S & S & S \\
\hline TS & S & S & S \\
\hline TS & S & S & S \\
\hline TS & S & S & S \\
\hline TS & S & S & GA \\
\hline TS & S & S & S \\
\hline
\end{tabular}

\begin{tabular}{|c|c|c|c|}
\hline \multicolumn{4}{|c|}{2017} \\
\hline O & F & C & Z \\
\hline TS & S & S & S \\
\hline TS & S & S & S \\
\hline TS & S & S & S \\
\hline TS & S & S & S \\
\hline TS & S & S & S \\
\hline TS & S & S & S \\
\hline
\end{tabular}




\begin{tabular}{|c|l|c|c|c|c|}
7 & MIDI & TS & S & S & S \\
\hline 8 & MPPA & TS & S & TS & S \\
\hline 9 & RANC & GA & S & TS & S \\
\hline 10 & SONA & TS & S & TS & S \\
\hline
\end{tabular}

\begin{tabular}{|c|c|c|c|} 
TS & $\mathrm{S}$ & $\mathrm{S}$ & $\mathrm{S}$ \\
\hline $\mathrm{TS}$ & $\mathrm{S}$ & $\mathrm{TS}$ & $\mathrm{S}$ \\
\hline $\mathrm{S}$ & $\mathrm{S}$ & $\mathrm{TS}$ & $\mathrm{S}$ \\
\hline $\mathrm{TS}$ & $\mathrm{S}$ & $\mathrm{TS}$ & $\mathrm{S}$ \\
\hline
\end{tabular}

\begin{tabular}{|c|c|c|c|} 
TS & $\mathrm{S}$ & $\mathrm{S}$ & $\mathrm{S}$ \\
\hline $\mathrm{TS}$ & $\mathrm{S}$ & $\mathrm{TS}$ & $\mathrm{S}$ \\
\hline $\mathrm{TS}$ & $\mathrm{S}$ & $\mathrm{TS}$ & $\mathrm{S}$ \\
\hline $\mathrm{TS}$ & $\mathrm{S}$ & $\mathrm{TS}$ & $\mathrm{S}$ \\
\hline
\end{tabular}

Sumber : Data Diolah

Keterangan :

$\mathrm{S} \quad=$ Sehat

TS $\quad=$ Tidak Sehat

GA $\quad=$ Grey Area

Untuk model Ohlson memprediksi hampir semua perusahaan dalam kondisi tidak sehat (Distress) tapi hanya model Ohslon saja dan model lain tidak menghasilkan yang sama kecuali perusahaan dengan kode MPPA, RANC dan SONA. MPPA adalah perusahaan yang berada pada kondisi tidak sehat pada tahun 2015 - 2017 serta model Ohlson dan CA - Score mampu memprediksi tingkat Distress.

RANC diprediksi model Ohlson mengalami kondisi Gray Area pada tahun 2015 dan tahun 2017 dalam kondisi tidak sehat seta tahun 2016 RANC dalam kondisi sehat. Model CA - Score memprediksi dalam kondisi tidak sehat tahun 2015 - tahun 2017.

SONA diprediksi model Ohlson dan CA - Score mengalami kondisi tidak sehat atau Distress pada tahun 2015 - 2017. Perhitungan semua model menunjukan bahwa HERO adalah perusahaan sehat tahun 2015, 2016 dan 2017, namun di tahun 2016 dan 2017 model Ohlson menunjukan bahwa HERO dalam kondisi tidak sehat. LPPF adalah perusahaan dalam konidisi sehat pada tahun 2015, 2016, dan 2017 namun pada tahun 2015 model Ohlson menunjukan dalam kondisi tidak sehat, serta tahun 2016 model Zavgren memprediksi HERO dalam kondisi Grey Area. 


\section{Perbandingan hasil perhitungan model Ohlson, model Fulmer, model CA-Score dan model Zavgre}

Tabel 2 Matrikulasi Hasil Perhitungan Model Ohlson, Model Fulmer

Model CA-Score dan Model Zavgren tahun 2015, 2016 dan 2017

\begin{tabular}{|c|c|c|c|c|c|c|c|c|c|}
\hline \multirow{2}{*}{ Kondisi } & \multirow{2}{*}{ Tahun } & \multicolumn{2}{|c|}{ Ohlson } & \multicolumn{2}{|c|}{ Fulmer } & \multicolumn{2}{|c|}{ CA - Score } & \multicolumn{2}{|c|}{ Zavgren } \\
\hline & & Jumlah & $\%$ & Jumlah & $\%$ & Jumlah & $\%$ & Jumlah & $\%$ \\
\hline \multirow{3}{*}{ Sehat } & 2015 & 1 & $10 \%$ & 10 & $100 \%$ & 7 & $70 \%$ & 10 & $100 \%$ \\
\hline & 2016 & 1 & $10 \%$ & 10 & $100 \%$ & 7 & $70 \%$ & 9 & $90 \%$ \\
\hline & 2017 & - & - & 10 & $100 \%$ & 7 & $70 \%$ & 10 & $100 \%$ \\
\hline \multirow{3}{*}{ Tidak Sehat } & 2015 & 8 & $80 \%$ & - & - & 3 & $30 \%$ & - & \\
\hline & 2016 & 9 & $90 \%$ & - & - & 3 & $30 \%$ & - & \\
\hline & 2017 & 10 & $100 \%$ & - & - & 3 & $30 \%$ & - & \\
\hline \multirow{3}{*}{ Grey Area } & 2015 & 1 & $10 \%$ & - & - & - & - & - & \\
\hline & 2016 & - & - & - & - & - & - & 1 & $10 \%$ \\
\hline & 2017 & - & - & - & - & - & - & - & \\
\hline \multicolumn{2}{|l|}{$\begin{array}{l}\text { Total Sampel } \\
\text { Pengamatan }\end{array}$} & \multicolumn{8}{|c|}{30} \\
\hline \multicolumn{2}{|c|}{$\begin{array}{l}\text { Prosentase Kondisi } \\
\text { sehat terhadap total } \\
\text { pengamatan }\end{array}$} & \multicolumn{2}{|r|}{$6,67 \%$} & \multicolumn{2}{|r|}{$100 \%$} & \multicolumn{2}{|r|}{$70 \%$} & \multicolumn{2}{|r|}{$96,67 \%$} \\
\hline \multicolumn{2}{|c|}{$\begin{array}{l}\text { Prosentase kondisi } \\
\text { tidak sehat terhadap } \\
\text { total pengamatan }\end{array}$} & \multicolumn{2}{|r|}{$90 \%$} & \multicolumn{2}{|r|}{-} & \multicolumn{2}{|r|}{$30 \%$} & \multirow{2}{*}{\multicolumn{2}{|c|}{$3,33 \%$}} \\
\hline \multicolumn{2}{|c|}{$\begin{array}{l}\text { Prosentase kondisi } \\
\text { Grey Area terhadap } \\
\text { total pengamatan }\end{array}$} & \multicolumn{2}{|r|}{$3,33 \%$} & \multicolumn{2}{|r|}{-} & & - & & \\
\hline
\end{tabular}

Hasil perhitungan model Ohlson memprediksi perusahaan - perusahaan ritel di Bursa Efek Indonesia dengan jumlah 10 perusahaan selama periode tahun $2015 \mathrm{~s} / \mathrm{d} 2017$ terdapat sebanyak 2 sampel perusahaan dalam keadaan sehat yaitu di tahun 2015 sebanyak 1 perusahaan (50\%) dan tahun 2016 sebanyak 1 perusahaan (50\%). Diperiode yang sama, model Ohlson memprediksi perusahaan dengan sampel sebanyak 27 sampel tidak sehat yaitu di tahun 2015 sebanyak 8 perusahaan $(29,63 \%)$, tahun 2016 sebanya 9 perusahaan $(33,33 \%$ dan di tahun 2017 terdapat 10 perusahaan $(37,04 \%)$. Di tahun yang sama model Ohlson juga memprediksi perusahaan dalam kondisi Grey Area yaitu 1 perusahaan (100\%) dalam kondisi Grey Area.

Hasil perhitungan model Fulmer memprediksi perusahaan-perusahaan ritel di Bursa Efek Indonesia dengan jumlah 10 perusahaan selama periode tahu 2015 s/d 2017 terdapat sebanyak 30 sampel (100\%) perusahaan dalam kondisi sehat.

Hasil perhitungan dengan model CA-Score memprediksi perusahaan-perusahaan ritel di Bursa Efek Indonesia dengan jumlah sampel 10 perusahaan dalam kondisi sehat terdapat 21 sampel. Tahun 2015 terdapat 7 sampel perusahaan sehat $(33,33 \%), 2016$ terdapat 7 sampel perusahaan sehat $(33,33 \%)$ dan 2017 terdapat 7 sampel perusahaan sehat $(33,33 \%)$. Di tahun yang sama model CA - Score memprediksi perusahaan dalam kondisi tidak sehat yaitu terdapat 9 sampel dalam kondisi tidak sehat. Tahun 2015 terdapat 3 sampel perusahaan $(33,33 \%)$ begitu pula dengan tahun 2016 dan 2017 memiliki hasil yang sama sehingga memperoleh hasil masing - 
masing tahun yaitu 33,33\%. Hasil perhitungan model Zavgren memprediksi perusahaanperusahaan ritel di Burs Efek Indonesia dengan jumlah sampel 29 sampel sehat. Tahun 2015 terdapat 10 sampel perusahaan $(34,48 \%)$, tahun 2016 terdapat 9 sampel perusahaan $(31,10 \%)$, dan 2017 terdapat 10 sampel sehat $(34,48)$. Ditahun yang sama model Zavgren memprediksi perusahaan dalam kondisi Grey Area yaitu terdapat 1 perusahaan sampel sehat (10\%).

Berdasarkan analisa data yang telah dijelaskan pada bagian-bagian sebelumnya, maka penelitian ini mendapakan hasil yang berbeda - beda untuk setiap model perhitungan yang dilakukan hasil prediksi berbagai model perhitungan yaitu model Ohlson, Fulmer, CA - Score dan Zavgren difokuskan kepada beberapa temuan beberapa perusahaan yang mengalami kondisi tidak sehat yang relatif berbeda setiap periode tahun penelitian.

Dengan menggunakan Model Ohlson, penulis mencoba berusaha melakukan prediksi atas perusahaan-perusahaan ritel yang terdaftar di BEI yang digunakan sebagai sampel, perusahaan yang akan diprediksi berjumlah 10 perusahaan pada tahun 2015 - 2017

Tabel 3 Model Ohlson

\begin{tabular}{|c|l|c|c|c|}
\hline \multirow{2}{*}{ No Nama Perusahaan } & \multicolumn{3}{c|}{ Model Ohlson } \\
\cline { 3 - 5 } & & 2015 & 2016 & 2017 \\
\hline 1 & PT. Sumber Alfaria Trijaya, Tbk (AMRT) & 4,080 & 4,433 & 4,895 \\
\hline 2 & PT. Catur Sentosa Adiprana, Tbk (CSAP) & 5,406 & 4,531 & 4,690 \\
\hline 3 & PT. Erajaya Swasembada, Tbk (ERAA) & 3,679 & 3,469 & 3,599 \\
\hline 4 & PT. Hero Supermarket, Tbk & $-0,37$ & 7,663 & 3,599 \\
\hline 5 & PT. Matahari Departmen Store, Tbk (LPPF) & 3,954 & 3,408 & 3,168 \\
\hline 6 & PT. Mitra Adiperkasa, Tbk (MAPI) & 7,048 & 6,69 & 6,372 \\
\hline 7 & PT. Midi Utama Indonesia, Tbk (MIDI) & 5,451 & 5,623 & 5,903 \\
\hline 8 & PT. Matahari Putra Prima, Tbk (MPPA) & 3,755 & 4,673 & 3,987 \\
\hline 9 & PT. Supra Boga Lestari, Tbk (RANC) & 0,870 & 1,956 & 3,469 \\
\hline 10 & PT. Sona Topas Tourism Industry, Tbk (SONA) & 2,870 & 2,817 & 2,310 \\
\hline
\end{tabular}

Sumber : Data Diolah

Berdasarkan tabel diatas semua perusahaan memiliki nilai Cut off lebih dari 0,38 yang artinya perusahaan tersebut diprediksi akan mengalami Financial Distress. perusahaan - perusahaan tersebut adalah PT. Sumber Alfaria Trijaya, Tbk, PT. Catur Sentosa Adiprana, Tbk, PT. Erajaya Swasembada, Tbk, PT. Matahari Departmen Store, Tbk, PT. Mitra Adiperkasa, Tbk, PT. Matahari Putra Prima, Tbk, PT. Sona Topas Tourism Industry, Tbk.

Satu hal yang perlu diingat adalah hasil prediksi model ini hanya memprediksi Financial Distress, bukan Operational Distress atau Likuidasi. Selain itu setiap model yang digunakan dalam memprediksi tidak pernah sempurna, "maka dari itu hasil prediksi ini tidak boleh dianggap sebagai hasil yang absolut. Hasil prediksi hanya sebatas indikator supaya investor atau kreditur lebih berhatihati atas perusahaan yang diprediksi mengalami Financial Distress dan mencari informasi tambahan mengenai Financial Distress”.

\section{KESIMPULAN DAN SARAN}

Berdasarkan hasil penyajian dan analisa data dalam memprediksi Financial Distress perusahaan ritel dengan menggunakan model Ohlson, model Fulmer, model CA-Score dan model Zavgren. Maka kesimpulan yang dapat diambil adalah sebagai berikut :

1. Model Ohlson dapat digunakan untuk memprediksi kesulitan keuangan pada perusahaan ritel dan memiliki tingkat paling tinggi dibanding dengan model lain dalam memprediksi perusahaan ritel 
tahun 2015 - 2017. Perbandingan analisis yang paling efektif dan akurat dalam memprediksi kondisi Financial Distress perusahaan ritel yang terdaftar di Bursa Efek Indonesia tahun 2015 2017 adalah model Ohlson.

2. Setelah dilakukan prediksi terhadap 10 perusahaan yang dijadikan sampel menggunakan model Ohlson diketahui ada 8 perusahaan yang diprediksi mengalami Financial Distress dimasa depan yaitu PT. Sumber Alfaria Trijaya, Tbk, PT. Catur Sentosa Adiprana, Tbk, PT. Erajaya Swasembada, Tbk, PT. Matahari Departmen Store, Tbk, PT. Mitra Adiperkasa, Tbk, PT. Matahari Putra Prima, Tbk, PT. Sona Topas Tourism Industry, Tbk.

Saran Bagi Peneliti selanjutnya diharapkan dapat melakukan penelitian dengan menambah periode dan sampel penelitian sehingga dapat membuktikan kebenaran prediksi pada perusahaanperusahaan yang diuji melalui model-model prediksi kesehatan perusahaan. Perusahaan juga bisa menambahkan model lain didalam penelitian selanjutnya seperti model Toffler yang belum banyak digunakan untuk meneliti.

\section{DAFTAR PUSTAKA}

Agarwal, A. and Patni, I. (2019) 'Bankruptcy prediction models: An empirical comparison', International Journal of Innovative Technology and Exploring Engineering, 8(6), pp. 131-139.

Aghajani, V., dan Jouzbarkand, M. (2012). "The Creation Of Bankruptcy Prediction Model Using Springate and SAF Models". International Proceedings of Economics Development and Research. Vol 54 No 2. DOI: 10.7763/IPEDR

Anggarini, T. V. dan M. D. Ardiyanto. (2010). "Pengaruh Karakteristik Komite Audit Terhadap Financial Distress". E-journal Universitas Dipponegoro

Amoa-Gyarteng, K. (2019) 'Financial Characteristics of Distressed Firms: An Application of the Altman Algorithm Model', Journal of Corporate Accounting \& Finance, 30(1), pp. 63-76. doi: 10.1002/jcaf.22367.

Ashraf, S., G. S. Félix, E. and Serrasqueiro, Z. (2019) 'Do Traditional Financial Distress Prediction Models Predict the Early Warning Signs of Financial Distress?', Journal of Risk and Financial Management, 12(2), p. 55. doi: 10.3390/jrfm12020055.

Agustina, Yeni dan Rahmawati. (2010). Kebangkrutan perusahaan menggunakan model Altman dan Zavgren pada perusahaan Food And Beverages. FEB Universitas Sebelas Maret. Surakarta.

Atmaja, Setiya Lukas. (2008). Teori dan Praktik Manajemen Keuangan. Yogyakarta: CV.ANDI OFFSET

Kusumaningtyas, Dega. (2017). Analisis Prediksi Kebangkrutan dengan menggunakan model Zmijewski, Springate, dan Fulmer pada Perusahaan Ritel di Bursa Efek Indonesia. Skripsi.STIE PERBANAS. Surabaya.

Musthafa, H. (2017). Manajemen Keuangan. Yogyakarta: CV. Andi Offset

Pratama, Yudhian Putra dkk. (2015). Prediksi kebangkrutan dengan menggunakan model Altman ZScore, Dan Zavgren. Jurnal e-Proceeding of Management volume 3 nomor 3.

Panigrahi, A. (2019) 'Validity of Altman' s " Z " Score Model in Predicting Financial Distress of Pharmaceutical Companies', IV(1), pp. 65-73.

Samanhyia, S., Oware, K. M. and Anisom-yaansah, F. (2016) 'Financial Distress and Bankruptcy Prediction: Evidence from Ghana', Expert Journal of Finance, 4(1), pp. 52-65.

Supriyanto, J. and Darmawan, A. (2018) 'the Effect of Financial Ratio on Financial Distress in Predicting Bankruptcy', Journal of Applied Managerial Accounting, 2(1), pp. 110-120. doi: 10.30871/jama.v2i1.727.

Wulandari, Veronita dkk. (2014). Analisis Perbandingan model Altman, Springate, Ohlson, Fulmer, CA-Score dan Zmijewski dalam memprediksi Financial Distress pada Perusahaan Food And Beverage yang terdaftar di BEI tahun 2010 - 2012. Jurnal. Universitas RIAU. Pekanbaru. 